\title{
TINGKAT KREATIVITAS SLOW LEARNERS DALAM MEMECAHKAN MASALAH MATEMATIKA
}

\author{
Rima Aksen Cahdriyana ${ }^{1}$, Rahayu Setyorini ${ }^{2}$ \\ ${ }^{1}$ Universitas Ahmad Dahlan \\ rima.cahdriyana@pmat.uad.ac.id \\ ${ }^{2}$ SMP Perintis Yogyakarta
}

\begin{abstract}
ABSTRAK
Heterogenitas siswa yang ada di Indonesia menjadi suatu tantangan bagi guru saat ini. Kreativitas bukan hanya diperuntukkan bagi siswa dengan kemampuan matematis yang tinggi, namun juga mulai diperkenalkan kepada siswa yang termasuk dalam kategori slow learner. Penelitian ini termasuk dalam penelitian deskriptif kualitatif yang bertujuan untuk mendeskripsikan tingkat kreativitas slow learners dalam memecahkan masalah matematika dan juga untuk mendeskripsikan langkah-langkah mengembangkan keterampilan berpikir kreatif bagi slow learners melalui literature review. Subjek penelitian berasal dari salah satu sekolah di Yogyakarta yang siswanya termasuk dalam kategori slow leaners. Subjek dipilih melalui teknik purposive sampling. Pengumpulan data dilakukan dengan memberikan soal pemecahan masalah kepada seluruh subjek, kemudian mewawancarainya guna mengklarifikasi jawaban yang telah dituliskan. Analisis data dihentikan pada subjek yang ketiga karena data dari subjek ketiga telah jenuh, yaitu sudah tidak ada lagi perbedaan data dari subjek sebelumnya. Hasil penelitian ini menunjukkan bahwa slow learners tidak mampu menunjukkan ketiga indikator kreativitas dalam memecahkan masalah matematika (kefasihan, fleksibilitas, dan kebaruan), sehingga slow learners tergolong dalam kemampuan berpikir kreatif tingkat 0 atau termasuk dalam siswa tidak kreatif. Temuan lain menunjukkan bahwa satu subjek terindikasi mampu menunjukkan satu indikator kreativitas yaitu kefasihan, sehingga tergolong dalam kemampuan berpikir kreatif tingkat 1 (kurang kreatif).
\end{abstract}

Kata Kunci: kreativitas, masalah, slow learners.

\begin{abstract}
The heterogeneity of students in Indonesia is a challenge for teachers today. Creativity is not only for students with high mathematical abilities, but also introduced to students who are in the slow learner category. This research is a qualitative descriptive study that aims to describe the level of creativity of the slow learner, and to describe how to develop creative thinking skills for slow learners. The subjects in this study from one of the schools in Yogyakarta whose students were included in the slow learner category. The subjects were selected by purposive sampling. Data collection had been done by giving problems solving to subjects, then interviewing them to clarify the answers that have been written. Data analysis had been stopped on the third subject because the data from the third subject was no difference with data from the previous subject. The results of this study indicate that slow learners are not able to show the three indicators of creativity in solving mathematical problems (fluency, flexibility, and novelty), so that the slow learners are classified as creative thinking skills
\end{abstract}


level 0 or included in not creative students. Other findings indicate that one subject indicated being able to show one indicator of creativity, namely fluency, so that subject classified as level 1 (almost not creative).

Keywords: creativity, problem, slow learners.

Format Sitasi: Cahdriyana, R.A., \& Setyorini, R. (2019). Tingkat Kreativitas Slow Learners dalam Memecahkan Masalah Matematika. KALAMATIKA Jurnal Pendidikan Matematika, 4(1), 1-14.

Penyerahan Naskah: 22 Juni 2018 || Revisi: 22 Januari 2019 || Diterima: 28 Januari 2019

\section{PENDAHULUAN}

Dalam peraturan menteri pendidikan dan kebudayaan nomor 21 tahun 2016 tentang standar isi pendidikan dasar dan menengah dijabarkan adanya Kompetensi Inti (KI) yang terdiri atas KI 1 hingga KI 4 yang meliputi sikap religius, sikap sosial, pengetahuan, dan keterampilan. Dalam kompetensi inti, keterampilan dideskripsikan dengan menunjukkan keterampilan berpikir dan bertindak: kreatif, produktif, kritis, mandiri, kolaboratif, dan komunikatif dalam bahasa yang jelas, sistematis, logis, dan kritis dalam karya yang estetis dan tindakan yang mencerminkan perilaku anak sesuai dengan tahap perkembangannya. Hal ini menunjukkan bahwa kreativitas menjadi satu bagian yang tidak dapat dipisahkan dalam pembelajaran yang menggunakan kurikulum 2013.

Berpikir kreatif adalah cara berpikir yang original dan menghasilkan produk yang kompleks. Berpikir kreatif dalam matematika merujuk pada kombinasi dari logika dan pola pikir divergen, yang berdasar pada intuisi namun mempunyai tujuan yang jelas (Siswono, 2011). Salah satu cara yang potensial digunakan untuk mengembangkan kemampuan berpikir kreatif siswa dalam matematika adalah dengan pemberian masalah open-ended (Maharani \& Sukestiyarno, 2017). Dengan memberikan masalah open-ended, siswa akan terbiasa menyelesaikan masalah dengan beragam cara/penyelesaian dan beragam alternatif jawaban. Menurut Santrock (2011: 368), langkah-langkah dalam menyelesaikan masalah adalah (1) menemukan dan menyusun masalah, (2) mengembangkan strategi pemecahan masalah, (3) mengevaluasi solusi, dan (4) memikirkan kembali masalah dan solusi.

Pengembangan model pembelajaran matematika dengan penilaian autentik yang didasarkan pada kurikulum 2013 merupakan alternatif model yang sangat baik untuk membangun keterampilan berpikir kreatif siswa (Sinaga, Harahap, Sinambela, \& Sinaga, 2016). Pembelajaran berbasis masalah merupakan salah satu model pembelajaran matematika 
yang didasarkan pada kurikulum 2013. Model tersebut dikembangkan berdasarkan paham konstruktivis yang menggabungkan antara teori Piaget dan Vygotsky. Pada model tersebut, terdapat suatu langkah dimana guru memberikan scafolding kepada siswa. Melalui tahap ini, tahap asimilasi dan akomodasi yang telah dilalui siswa mampu berlanjut menuju tahap ekuilibrasi (Cahdriyana, 2016). Oleh karena itu, pengembangan keterampilan berpikir kreatif siswa dapat dilakukan dengan memberikan scafolding saat siswa mengalami kesulitan dalam menyelesaikan masalah open-ended.

Tingkat kreativitas seorang siswa dapat ditentukan dengan mengidentifikasi indikator kreativitas yang muncul saat menyelesaikan masalah matematika. Indikator yang dimaksud adalah kefasihan, fleksibilitas, dan kebaruan (Siswono, 2011). Kefasihan merujuk pada lebih dari satu alternatif jawaban/solusi yang mampu diberikan oleh siswa. Fleksibilitas merujuk pada lebih dari satu cara/penyelesaian yang mampu diberikan oleh siswa, sedangkan kebaruan merujuk pada salah satu solusi atau cara yang diberikan siswa berbeda dari solusi atau cara yang biasa dilakukan oleh guru di dalam kelas.

Kreativitas siswa dalam memecahkan masalah matematika mempunyai beberapa tingkatan. Perbedaan dari setiap tingkatan didasarkan ketiga indikator: kefasihan, fleksibilitas, dan kebaruan. Siswa pada tingkat 4, mampu menunjukkan ketiga komponen dari indikator berpikir kreatif. Siswa pada tingkat 3, memenuhi dua komponen yaitu kefasihan dan fleksibilitas, atau kebaruan dan kefasihan. Siswa pada tingkat 2 hanya mampu menunjukkan satu aspek yaitu fleksibilitas atau kebaruan, dan siswa pada tingkat 1 hanya mampu menunjukkan indikator kefasihan. Sedangkan siswa pada tingkat 0 tidak mampu menunjukkan ketiga komponen dari indikator berpikir kreatif. Setiap tingkatan kreativitas mempunyai penyebutan masing-masing, seperti: tingkat 4 disebut very creative, tingkat 3 disebut creative, tingkat 2 disebut quite creative, tingkat 1 disebut almost not creative, dan tingkat 0 disebut not creative (Siswono, 2011).

Heterogenitas siswa yang ada di Indonesia menjadi suatu tantangan bagi guru saat ini. Kreativitas bukan hanya diperuntukkan bagi siswa dengan kemampuan matematis yang tinggi, namun juga mulai diperkenalkan kepada siswa yang termasuk dalam kategori slow learners. Slow learners tidak memiliki perbedaan yang menonjol dengan teman-teman sebayanya, mereka hanya lambat dalam menyerap informasi, dan memiliki IQ (Intelligence Quotients) antara 76 dan 89 sehingga memiliki prestasi yang terbatas (Chauhan, 2011). 
Banyak gejala dan tanda yang dimunculkan dari slow learners, seperti kepercayaan diri yang rendah, pemalu, dan sering merasa tidak nyaman dengan lingkungannya. Slow learners sering mengalami masalah dalam memahami suatu soal atau masalah, sering menghapus pekerjaan yang telah dituliskan dalam buku tulis, tidak mau mengambil resiko dari tantangan yang diberikan guru, mempunyai kosakata yang terbatas sehingga sulit dalam menyampaikan kemauannya, lambat dalam merespon ketika ditanya guru, dan lain sebagainya (Turi, Ghani, Javid, \& Sorooshian, 2017). Gejala-gejala tersebut mengindikasikan bahwa kurangnya

perhatian dan dorongan yang diberikan kepada slow learners, salah satunya dari pihak sekolah. Terdapat banyak cara yang dapat dilakukan guru untuk mendorong siswanya yang sebelumnya berada pada kategori slow learners supaya beralih berada pada middle bahkan front line (Turi, Ghani, Javid, \& Sorooshian, 2017). Oleh karena itu, pandangan bahwa slow learners tidak mampu mempunyai keterampilan berpikir kreatif harus disingkirkan bagi seorang guru. Melalui artikel ini akan dibahas bagaimana tingkat kreativitas slow learners dalam memecahkan masalah matematika, dan bagaimana mengembangkan keterampilan berpikir kreatif bagi slow learners.

\section{METODE PENELITIAN}

Penelitian ini merupakan penelitian deskriptif kualitatif dengan tujuan untuk mendeskripsikan tingkat kreativitas slow learners dalam memecahkan masalah matematika. Selain itu, juga dideskripsikan bagaimana mengembangkan keterampilan berpikir kreatif bagi slow learners melalui literature review. Subjek dalam penelitian ini berasal dari salah satu sekolah di Yogyakarta yang siswanya termasuk dalam kategori slow learners. Subjek dipilih melalui teknik purposive sampling, yaitu pemilihan subjek berdasarkan rekomendasi guru. Subjek yang dipilih adalah subjek dengan kemampuan komunikasi yang baik, sehingga peneliti dapat menggali informasi yang dibutuhkan. Pengumpulan data dilakukan dengan memberikan soal pemecahan masalah kepada seluruh subjek, kemudian mewawancarainya guna mengklarifikasi jawaban yang telah dituliskan. Analisis data dilakukan dengan membandingkan data antar subjek. Analisis data dihentikan pada subjek yang ketiga karena data dari subjek ketiga sudah jenuh, yaitu sudah tidak ada lagi perbedaan data dari subjek sebelumnya. Hasil tes dianalisis dengan mengidentifikasi jawaban yang benar kemudian menentukan manakah dari ketiga indikator kreativitas (kefasihan, fleksibilitas, dan kebaruan) yang muncul. Ketiga indikator kreativitas dipilih karena fokus pemecahan masalah yang 
dimaksud terdapat pada masalah open ended. Masalah open ended atau yang biasa disebut dengan masalah divergen merujuk pada masalah yang mempunyai beberapa solusi jawaban dan beberapa cara/penyelesaian yang berbeda. Berdasarkan indikator kreativitas yang muncul, kemudian ditentukan tingkat kreativitas slow learners dalam memecahkan masalah matematika.

\section{HASIL DAN PEMBAHASAN}

Instrumen tes pemecahan masalah matematika terdiri atas tiga item soal dengan multijawaban benar serta memiliki indikator pemecahan masalah matematika dan kreativitas. Instrumen tersebut telah divalidasi oleh dua orang validator. Validator pertama dipilih karena dipandang sebagai pakar/ahli dalam pengembangan instrumen soal matematika open ended, sedangkan validator kedua dipilih karena sebagai guru pengampu mata pelajaran matematika di sekolah tempat penelitian, sehingga mengetahui karakteristik dari siswa-siswa yang akan dijadikan subjek penelitian.

Secara umum, hasil validasi dapat disimpulkan bahwa instrumen tes dapat digunakan setelah revisi. Revisi dilakukan berdasarkan saran-saran dari kedua validator. Validator pertama memberikan saran untuk menambahkan satu kalimat yang bertujuan untuk menjembatani siswa yang belum terbiasa dengan soal open-ended. Sedangkan validator kedua memberikan saran agar menurunkan tingkat kesukaran soal melihat karakteristik siswa yang termasuk dalam slow learners, sehingga soal awal yang menuntut siswa menggunakan banyak langkah penyelesaian, diturunkan kesukarannya menjadi beberapa langkah penyelesaian yang sederhana. Validator kedua juga memberikan saran untuk mengubah beberapa kata dalam soal yang belum tepat dalam menggunakan Bahasa Indonesia yang baik dan benar. Berikut ini adalah bagian awal dari soal pemecahan masalah setelah divalidasi. 


\section{Kerjakan tugas berikut.}

Seekor sapi mempunyai tiga bagian, yaitu kepala, badan, dan kaki.

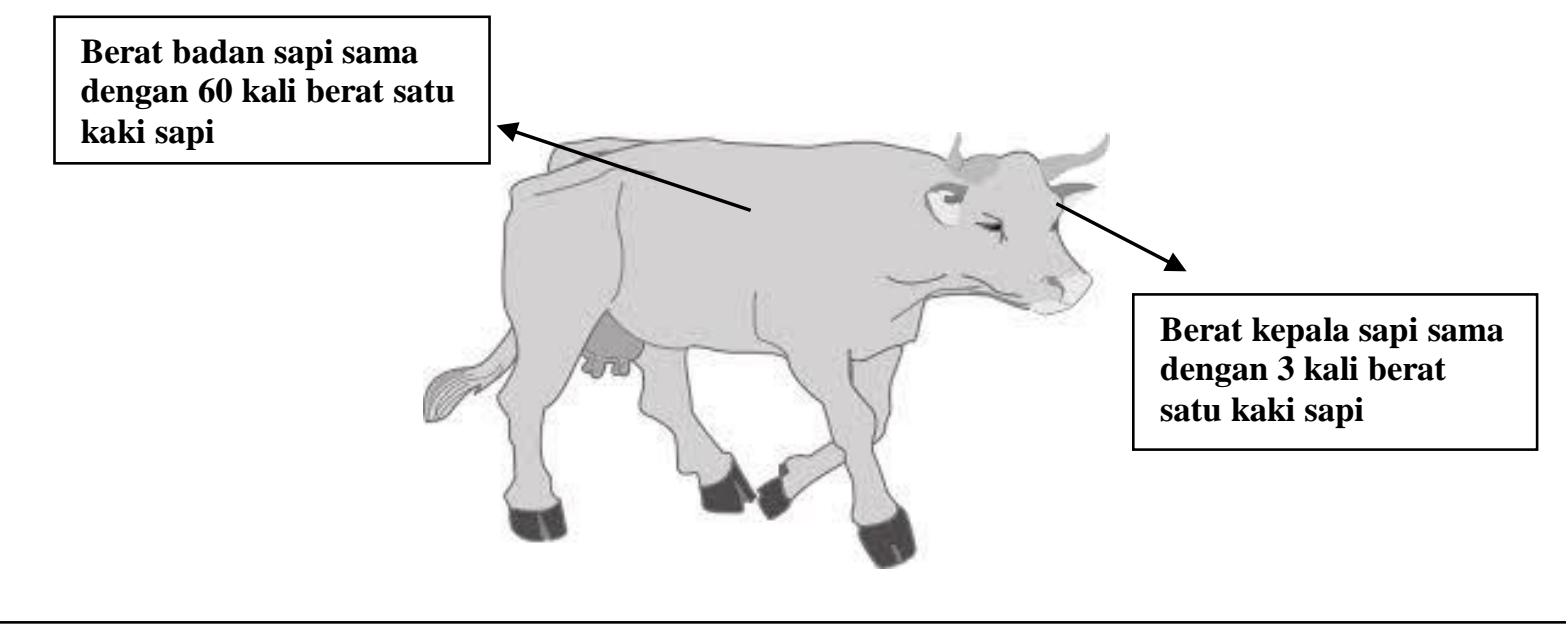

Gambar 1. Soal Tes Pemecahan Masalah

Pada Gambar 1, diketahui adanya berat kaki sapi yang menunjukkan bahwa soal tersebut bersifat open-ended, karena hanya dengan mengganti berat kaki sapi dengan suatu bilangan tertentu, akan diperoleh berat sapi yang berbeda. Tabel 1 berikut adalah bagian lain dari soal pemecahan masalah disertai dengan indikator pemecahan masalah dan kreativitas.

Tabel 1. Soal Tes Pemecahan Masalah

\begin{tabular}{lcc}
\hline \multicolumn{1}{c}{ Pertanyaan Soal } & $\begin{array}{c}\text { Indikator Pemecahan } \\
\text { Masalah }\end{array}$ & $\begin{array}{c}\text { Indikator } \\
\text { Kreativitas }\end{array}$ \\
\hline Berapa kemungkinan berat seekor sapi itu? & $\begin{array}{c}\text { Menemukan dan menyusun } \\
\text { masalah }\end{array}$ & Kefasihan \\
$\begin{array}{l}\text { Misalkan berat satu kaki sapi adalah 5 kg, maka } \\
\text { berapakah berat seekor sapi itu? }\end{array}$ & $\begin{array}{c}\text { Mengembangkan strategi } \\
\text { pemecahan masalah }\end{array}$ & - \\
$\begin{array}{l}\text { Apakah ada kemungkinan jawaban lain yang berbeda? } \\
\text { Bila ada sebutkan kemungkinan-kemungkinan jawaban } \\
\text { itu paling sedikit dua kemungkinan. }\end{array}$ & Mengevaluasi solusi \\
$\begin{array}{l}\text { Periksalah jawaban yang telah kamu peroleh. Tunjukkan } \\
\text { dua atau lebih cara yang berbeda untuk mendapatkan } \\
\text { jawaban itu. }\end{array}$ & $\begin{array}{c}\text { Memikirkan kembali masalah } \\
\text { dan solusi }\end{array}$ & Kefasihan dan kebaruan \\
\hline
\end{tabular}

Pada Tabel 1, soal pertama menunjukkan indikator pertama dalam pemecahan masalah matematika yaitu menemukan dan menyusun masalah. Melalui soal ini, siswa diminta untuk mendeskripsikan informasi, tanpa membuat simbol-simbol. Soal kedua menunjukkan indikator kefasihan dan kebaruan (dalam kreativitas), dan mengembangkan strategi pemecahan masalah dan mengevaluasi solusi (dalam pemecahan masalah). Melalui soal ini, siswa dapat menuliskan ragam jawaban (solusi). Soal ketiga menunjukkan indikator fleksibilitas (dalam 
kreativitas), dan memikirkan kembali masalah dan solusi (dalam pemecahan masalah). Melalui soal ini, siswa diminta untuk menuliskan ragam cara/penyelesaian yang dapat digunakan memecahkan masalah yang diberikan.

Tabel 2. Analisis Data Setiap Subjek

\begin{tabular}{|c|c|c|c|}
\hline Soal Tes & Subjek RN & Subjek SLR & Subjek AGL \\
\hline Soal No.1 & $\begin{array}{l}\text { Subjek RN mampu memahami } \\
\text { pernyataan-pernyataan dalam soal, } \\
\text { sehingga dalam menyelesaikan } \\
\text { soal yang pertama, subjek RN } \\
\text { mampu menunjukkan jawaban } \\
\text { dan langkah penyelesaian yang } \\
\text { benar. }\end{array}$ & $\begin{array}{l}\text { Subjek SLR tidak mampu } \\
\text { memahami pernyataan yang } \\
\text { diketahui dari soal sehingga } \\
\text { langkah penyelesaian yang } \\
\text { dituliskan kurang tepat. }\end{array}$ & $\begin{array}{l}\text { Subjek AGL memberikan jawaban yang salah } \\
\text { Subjek AGL mengalikan } 60 \text { dengan } 3 \text { untuk } \\
\text { mendapatkan berat sapi seluruhnya. Dari } \\
\text { jawaban yang dituliskan, menunjukkan bahwa } \\
\text { subjek AGL tidak memahami pernyataan yang } \\
\text { diketahui dalam soal. Subjek AGL mengambil } \\
\text { bilangan } 60 \text { dan } 3 \text { dari dua pernyataan dalam } \\
\text { soal. }\end{array}$ \\
\hline Soal No. 2 & $\begin{array}{l}\text { Subjek RN mampu memberikan } \\
\text { ragam jawaban dengan } \\
\text { memisalkan berat satu kaki sapi } \\
3 \text { kg dan } 6 \mathrm{~kg} \text {, sehingga didapat } \\
\text { berat sapi seluruhnya yang } \\
\text { berbeda. Sehingga dapat } \\
\text { disimpulkan bahwa subjek RN } \\
\text { mampu menunjukkan indikator } \\
\text { kefasihan. }\end{array}$ & $\begin{array}{l}\text { Subjek SLR tidak mampu } \\
\text { menunjukkan indikator kefasihan } \\
\text { dan kebaruan. Subjek SLR tidak } \\
\text { mampu menunjukkan ragam } \\
\text { jawaban (yang berbeda) yang } \\
\text { benar. Subjek SLR hanya } \\
\text { menjumlahkan berat kaki sapi } \\
\text { dengan berat kepala sapi, tanpa } \\
\text { menjumlah berat badan sapi, } \\
\text { sehingga berat badan sapi } \\
\text { seluruhnya yang dituliskan kurang } \\
\text { tepat. }\end{array}$ & $\begin{array}{l}\text { Subjek AGL menjumlahkan berat kepala sapi } \\
\text { dengan berat badan sapi. Subjek AGL belum } \\
\text { menjumlahkan berat kaki sapi untuk } \\
\text { memperoleh berat sapi seluruhnya. Oleh } \\
\text { karena itu subjek AGL memberikan jawaban } \\
\text { yang kurang tepat dikarenakan kurangnya } \\
\text { langkah penyelesaian. }\end{array}$ \\
\hline Soal No.3 & $\begin{array}{l}\text { Subjek RN tidak mampu } \\
\text { menunjukkan indikator } \\
\text { fleksibilitas dan kebaruan karena } \\
\text { subjek RN tidak dapat } \\
\text { menunjukkan cara/ penyelesaian } \\
\text { lain yang berbeda dari cara yang } \\
\text { telah dituliskan di nomor satu dan } \\
\text { dua. }\end{array}$ & $\begin{array}{l}\text { Subjek SLR tidak mampu } \\
\text { memenuhi indikator fleksibilitas. } \\
\text { hal ini terlihat karena subjek SLR } \\
\text { tidak mampu menunjukkan } 2 \text { cara } \\
\text { yang berbeda dalam mencari berat } \\
\text { badan sapi seluruhnya. Jawaban } \\
\text { yang diberikan pun salah. }\end{array}$ & $\begin{array}{l}\text { Subjek AGL tidak mampu menunjukkan } \\
\text { langkah penyelesaian yang berbeda. Subjek } \\
\text { AGL juga tidak menuliskan jawaban untuk } \\
\text { nomor tiga. }\end{array}$ \\
\hline
\end{tabular}

Tabel 2 menunjukkan rangkuman analisis data setiap subjek dan tingkat kreativitasnya dalam memecahkan masalah matematika.

Tabel 3. Ringkasan Tingkat Kreativitas Slow Learners dalam Menyelesaikan Masalah Matematika

\begin{tabular}{cccccc}
\hline \multirow{2}{*}{ Inisial Siswa } & \multicolumn{3}{c}{ Indikator Kreativitas } & Tingkat & \multirow{2}{*}{ Keterangan } \\
\cline { 2 - 4 } & Kefasihan & Fleksibilitas & Kebaruan & Kreativitas & \\
\hline RN & $\checkmark$ & - & - & Tingkat 1 & Temuan lain \\
SLR & - & - & - & Tingkat 0 & Temuan utama \\
AGL & - & - & - & Tingkat 0 & Temuan utama \\
\hline
\end{tabular}

Tabel 3 menunjukkan bahwa temuan utama berasal dari subjek SLR dan AGL. Kedua subjek tidak mampu menunjukkan ketiga indikator kreativitas (kefasihan, fleksibilitas, dan kebaruan), sehingga SLR dan AGL tergolong dalam kemampuan berpikir kreatif tingkat 0 atau termasuk dalam siswa tidak kreatif. Temuan lain menunjukkan bahwa satu subjek yaitu subjek RN mampu menunjukkan satu indikator kreativitas yaitu kefasihan, sehingga tergolong dalam kemampuan berpikir kreatif tingkat 1 (kurang kreatif). Ketiga subjek dalam penelitian ini berasal dari sekolah yang siswanya tergolong dalam slow learner. Slow learners adalah 
salah satu bagian yang tak kalah penting dalam sistem pendidikan di Indonesia. Studi mengenai slow learners sangat diperlukan guna mendapatkan solusi/penanganan yang tepat dari kesulitan-kesulitan yang dihadapi dalam proses pembelajaran.

Seperti siswa pada umumnya, slow learners dapat dibentuk dan dikembangkan kemampuan matematisnya. Menjalin hubungan yang saling support dengan slow learners, menjadi teman baik dan fleksibel dengan polah tingkahnya, merupakan salah satu strategi yang dapat dilakukan guru sebagai salah satu upaya mengenali karakteristik unik dari slow learners yang dihadapinya. Mengadopsi suatu model pembelajaran dengan mempertimbangkan karakteristik tersebut, dapat membantu slow learners untuk mengeksplorasi kemampuannya yang tersembunyi. Guru juga dapat menggunakan bahasa yang sederhana dan mudah untuk dipahami oleh slow learners, baik dalam berkomunikasi secara langsung ataupun dalam menyampaikan informasi dalam bahasa tulis. Oleh karena itu, guru seharusnya menghindari kalimat yang terlalu panjang, tetapi lebih baik memotong kalimat yang panjang menjadi rangkaian kata yang pendek sehingga mudah dipahami. Selain itu, guru juga dapat berbicara tidak terlalu cepat dan mampu melihat respon slow learners dari setiap makna yang telah disampaikan karena terkadang slow learners membutuhkan pengulangan dari informasi tersebut (Turi et al., 2017).

Pembaharuan pendekatan pedagogik untuk meningkatkan kemampuan numerik/berhitung pada slow learners juga perlu untuk dilakukan (Mumpuniarti, 2017). Pernyataan ini didasarkan pada penelitian yang menunjukkan bahwa slow learners mempunyai banyak masalah pada praktik berhitung seperti masalah pada penjumlahan, pengurangan, perkalian, dan pembagian, baik pada operasi hitung bilangan bulat, pecahan, ataupun aljabar. Numeracy skills atau keterampilan berhitung merupakan keterampilan dasar. Setiap topik materi dalam matematika selalu bersinggungan dengan hitungan. Oleh karena itu, pengembangan kreativitas slow learners harus dimulai dengan pembiasaan menyelesaikan masalah matematika, sedangkan pengembangan keterampilan pemecahan masalah harus dimulai dari pengembangan keterampilan dasar matematis siswa, salah satunya adalah keterampilan berhitung.

Strategi pengajaran pedagogis yang sistematis sangat membantu slow learners untuk meningkatkan keterampilan berhitungnya. Universal learning design (ULD) adalah rencana belajar yang dapat membantu guru menemukan kebutuhan belajar siswa dengan memberikan 
variasi media, variasi pendekatan pembelajaran, dan variasi aktivitas, serta melibatkan siswa dalam merancang aktivitas pembelajaran. Melalui ULD, kebutuhan slow learners dalam pembelajaran dapat terpenuhi (Mumpuniarti, 2017).

Dalam mendesain pembelajaran, seorang guru harus memperhatikan elemen-elemen dasar yang dibutuhkan oleh slow learners. Elemen-elemen dasar tersebut adalah motivasi, perhatian individu, pengulangan materi, pengembangan kepercayaan diri, kurikulum yang fleksibel, pembelajaran remidial, lingkungan yang sehat, dan pembelajaran dengan metode khusus (Chauhan, 2011). Selain itu, pencapaian pembelajaran yang efektif bagi slow learners juga harus memperhatikan beberapa hal berikut. (1) Materi pelajaran harus direncanakan dengan penuh kehati-hatian dengan mempertimbangkan kapasitas siswa, (2) waktu yang dialokasikan untuk menyampaikan materi pelajaran, (3) slow learners lebih mudah menangkap materi konkret daripada materi yang abstrak, (4) pendekatan pembelajaran dengan teman sebaya memungkinkan adanya pengajaran remidial bagi slow learners, (5) fokus pada keterampilan sosial dan peningkatan kepercayaan diri slow learners, menekankan pada keefektivan penggunaan musik atau seni dalam pembelajaran, (6) persiapan pada bagian penting dari materi yang perlu diulang kembali, serta (7) perlunya penggunaan audio dan visualisasi materi, (8) penerapan strategi pembelajaran tuntas (mastery learning strategy) atau modular instruction, dan (9) computer assisted instruction (CAI) (Chauhan, 2011).

Setiap siswa mempunyai kemampuan kreatif, begitu juga pembelajaran yang kreatif dapat mendorong kreativitas siswa termasuk kreativitas slow learners. Terdapat banyak program multisensori yang diterapkan bagi siswa yang mengalami kesulitan dalam belajar. Salah satunya adalah penerapan CAI dalam pembelajaran. CAI adalah pembelajaran individual yang diberikan melalui komputer. Program CAI menekankan bukan hanya pada drill dan latihan, namun juga mengajarkan pengetahuan faktual dan konseptual. CAI menyediakan umpan balik yang sangat diperlukan bagi slow learners untuk mempertajam pembelajaran yang telah diikuti. Melalui CAI, (1) slow learners dapat belajar dengan alur pembelajaran yang disesuaikan dengan tingkat kemampuannya, (2) slow learners tidak akan mengalami kekerasan saat menemui hambatan dalam pembelajaran, misalnya: tidak akan mendapat ejekan saat mereka tidak mampu menjawab pertanyaan tertentu dan tidak akan mendapatkan pukulan/cubitan jika tidak kunjung paham dengan materi yang diajarkan, (3) slow learners merasa aman dalam belajar, bebas memilih menu, dan mendapati suasana yang 
santai tanpa tekanan dari pihak manapun. Hal ini akan menjadikan dorongan bagi slow learners untuk belajar lebih baik lagi dan mampu menunjukkan peningkatan prestasinya (Chauhan, 2011).

Pemilihan program CAI dalam proses pembelajaran harus mempertimbangkan karakteristik CAI yang efektif. Program CAI yang efektif digunakan oleh siswa adalah sebagai berikut. (1) tujuan pembelajaran jelas, (2) materi sesuai dengan kompetensi yang ingin dicapai, (3) konsep materi yang disajikan benar, (4) penjelasan materi sesuai dengan kemampuan berpikir siswa, (5) alur pembelajaran jelas, (6) terdapat petunjuk yang jelas, (7) terdapat apersepsi, (8) terdapat kesimpulan, contoh, dan latihan yang disertai umpan balik, (9) dapat membangkitkan motivasi belajar siswa, (10) terdapat evaluasi yang disertai dengan pembahasan dan hasil evaluasi, (11) gambar, animasi, teks, dan warna tersaji secara serasi, harmonis, dan proporsional, (12) interaktif, (13) navigasi mudah, dan (14) bahasa yang digunakan mudah dipahami oleh siswa (Cahdriyana \& Richardo, 2017).

Beberapa studi yang lain menunjukkan karakteristik dari CAI yang dapat digunakan oleh slow learners. Karakteristik tersebut didapatkan dari studi terhadap beberapa program CAI yang dirancang khusus bagi slow learners (Ahmad \& Mutalib, 2015). Technological Persuasive Pedagogy, merupakan salah satu keterampilan dasar yang harus dimiliki oleh guru untuk membantu siswa mengembangkan keterampilan dan kemampuannya, yaitu mampu mempengaruhi sikap siswa (kepercayaan diri, perilaku) terhadap matematika (Gharbaghi, Aris, Ahmad, \& Rosli, 2013). Terdapat tiga kondisi dimana guru seharusnya mampu merubah kondisi sikap siswa terhadap matematika. Pertama, merubah sikap negatif siswa terhadap matematika menjadi sikap positif terhadap matematika. Kedua, meningkatkan sikap positif siswa terhadap matematika. Ketiga, mencegah perubahan sikap positif siswa terhadap matematika menuju sikap negatif. Technological Persuasive Pedagogy dapat didukung melalui penerapan CAI (Gharbaghi et al., 2013), dan CAI dapat diimplementasikan dengan menerapkan persuasion concept (Ahmad \& Mutalib, 2015).

Langkah-langkah pembelajaran yang menerapkan CAI mempunyai banyak keuntungan, diantaranya: dapat mengintegrasikan ragam media yang ada, melibatkan beberapa cara/sudut pandang dalam menjelaskan suatu materi matematika, merepresentasikan materi baik secara verbal maupun grafik, dan mampu menggunakan prinsip psikologi dari Gestalt melalui pengorganisasian stimulus. Slow learners sering diasosiasikan dengan kondisi dimana 
tidak perlunya penyelesaian tugas berbasis pencil and paper. Aktivitas alternatif yang dapat diberikan kepada slow learners adalah eksperimen, simulasi, games, presentasi, musik, film, atau yang lainnya. Salah satu penggunaan CAI yang mudah diterapkan pada slow learners adalah dengan memberikan kebebasan merancang presentasi menggunakan power point sehingga slow learners bebas berekspresi menggunakan warna, tulisan, background, pilihan gambar, suara, jenis teks, video, dan lain sebagainya. Perancangan presentasi menggunakan power point dalam menyampaikan hasil tugas yang diberikan oleh guru membuat slow learners bebas berekspresi sehingga tidak membatasi kreativitasnya (Obradović, Bjekić, \& Zlatić, 2015).

Selain penggunaan CAI dan pemilihan desain pembelajaran bagi slow learners, pandangan lain yang mempengaruhi keberhasilan slow learners dalam mengembangkan kreativitasnya adalah perlunya motivasi dan regulasi diri. Berbagai penelitian terkait motivasi siswa yang mengalami kesulitan belajar (termasuk diantaranya slow learners) menyatakan bahwa pengalaman slow learners pada kegagalan dalam suatu mata pelajaran membuat kepercayaan dirinya berkurang, mempengaruhi harapannya untuk sukses yang semakin turun, dan munculya perilaku maladaptif. Slow learners memiliki emosi negatif yang lebih tinggi dan sering memunculkan rasa putus asa saat mereka merasa tidak mampu mengikuti pembelajaran dengan baik. Siswa dengan kesulitan belajar sering mencari bantuan untuk menyelesaikan tugas semata hanya karena menggugurkan kewajiban, bukan karena ingin menguasai materi lebih dalam (Lichtinger \& Kaplan, 2015).

Regulasi diri atau pengaturan diri siswa dalam belajar setidaknya mempunyai tiga karakteristik, yaitu (1) self-observation, dimana siswa mampu memonitor aktivitas apa yang sudah dilakukannya, (2) self-judgement, dimana siswa mampu mengevaluasi terhadap aktivitas yang telah dijalaninya, dan (3) self-reactions, dimana siswa mampu memberikan respon/rencana tindak lanjut terhadap aktivitas yang telah dilaluinya. Ketiga karakteristik tersebut menunjukkan bahwa belajar dan pembelajaran, bukan hanya merujuk pada perbaikan sikap seorang siswa, namun juga perbaikan prestasi akademis melalui strategi kognitif dan metakognitif. Strategi kognitif merupakan suatu latihan yang bertujuan pada penguasaan suatu pengetahuan dan keterampilan, sedangkan strategi metakognitif merujuk pada kesadaran siswa untuk memonitor pembelajaran yang telah dialaminya. Strategi metakognitif dapat dilakukan 
dengan melibatkan guru dan teman lain untuk membantu mereview akan aktivitas yang telah dijalaninya (Broadbent \& Poon, 2015).

\section{KESIMPULAN}

Studi mengenai slow learners sangat diperlukan guna mendapatkan solusi/penanganan yang tepat dari kesulitan-kesulitan yang dihadapi dalam proses pembelajaran. Temuan utama dalam penelitian ini menyimpulkan bahwa slow learners tergolong dalam kemampuan berpikir kreatif tingkat 0 atau termasuk dalam siswa tidak kreatif. Beberapa tindakan yang dapat dilakukan untuk mengembangkan keterampilan berpikir kreatif bagi slow learners adalah dengan memberikan desain pembelajaran yang disesuaikan dengan karakteristik slow learners, menggunakan ragam media pembelajaran salah satunya adalah CAI, menggunakan bahasa yang sederhana saat menyampaikan informasi, mengembangkan regulasi diri atau pengaturan belajar slow learners melalui strategi metakognitif, dan meningkatkan motivasi belajar melalui penumbuhan positive emotions.

\section{REFERENSI}

Ahmad, S.Z., \& Mutalib, A.A. (2015). Exploring Computer Assisted Learning for Low Achieving Children: A Comparative Analysis Study. Jurnal Teknologi, 77(29).

Broadbent, J., \& Poom, W.L. (2015). Self-Regulated Learning Strategies \& Academic Achievment in online Higher Education Learning Enviroments: A systematic Review. The Internet and Higer Education, 27, 1-13.

Cahdriyana, R.A. (2016). Pengaruh Metode Pembelajaran Berbasis Masalah Terhadap kemampuan Memecahkan Masalah Matematika Siswa SMP Negeri 9 Yogyakarta. AdMathEdu. Jurnal Ilmiah Pendidikan Ilmu Matematika dan Matematika Terapan. $6(2)$.

Cahdriyana, R.A., \& Richardo, R. (2017). Karakteristik Media Pembelajaran Berbasis Komputer untuk Siswa SMP. Alphamath, 2(2).

Chauhan, S. (2011). Slow Learners: Their Psycology and Educational Programmes. International Journal of Multidisciplinary Research, 1(8),279-289. 
Gharbaghi, A., Aris, B., Ahmad, M.H., \& Rosli, M.S. (2013). Technological Persuasive Pedagogy: A new Way to Persuade Students in the Computer-Based Mathematics Learning. Journal of Education and Practice, 4(14), 43-48.

Lichtinger, E., \& Kaplan, A. (2015). Employing a Case Study Approach to Capture Motivation and Self-Regulation of Young Students with Learning Disabilities in Authentic Educational Contexts. Metacognition and Learning, 10(1), 119-149.

Maharani, H.R., \& Sukestiyarno, S. (2017). Learning Analysisi Based on Humanism Theory and Mathematics Creative Thinking Ability of Students. Journal of Mathematics, 1(1).

Mumpuniarti, M. (2017). Challenges Faced by Teachers in Teaching Literacy and Numeracy for Slow Learners. Journal of Sustainable Development, 10(3), 243.

Obradovic, S., Bjekic, D., \& Zlatic, L. (2015). Creative Teaching with ICT Support for Students with Specific Learning Disabilities. Procedia-Social and Behavioral Sciences, 203, 291-296.

Santrock, J. W. (2011). Education Psychology - Third Edition. New York: McGraw-Hill.

Sinaga, B., Harahap, M., Sinambela, P.N., \& Sinaga, L. (2016). The Development of Mathematics Instructional and Authentic Assessment Model Based on Curriculum 2013 to Improve the Attitude Quality, Creative Thinking Ability and Mathematics Connections of High School Students. Proceeding AISTEEL The First Annual International Seminar on Transformative Education and Educational Leadership, 266-274.

Siswono, T.Y.E. (2011). Level of Student's Creative Thinking in Classroom Mathematics. Educational Research and Reviews, 6(7), 548-553.

Turi, J.A., Ghani, M.F.A., Javid, Y., \& Sorooshian, S. (2017). Teachers's Instructional Strategies to Support Slow Learners in Selected Schools, The Islamic Republic of Pakistan. Online Journal of Islamic Education, 5(2). 
